\title{
ANALISIS FAKTOR-FAKTOR YANG MEMPENGARUHI KINERJA PERAWAT GIGI DALAM PELAKSANAAN KEGIATAN UKGS (USAHA KESEHATAN GIGI SEKOLAH) DI PUSKESMAS WILAYAH DINAS KESEHATAN KABUPATEN BANDUNG
}

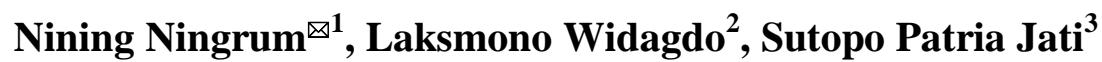

\begin{abstract}
ABSTRAK
Data penyakit gigi dan mulut di Kabupaten Bandung menunjukkan bahwa siswa menderita gusi berdarah, karies gigi siswa cenderung meningkat hampir mencapai 90\%. Rata-rata DMF-T umur 6-12 mencapai 2, sedangkan target Indonesia sehat 2010 kejadian karies tidak boleh lebih dari 2. Belum optimalnya pelayanan kesehatan gigi dan mulut pada anak usia sekolah dasar, menunjukkan bahwa kinerja perawat gigi dalam pelaksanaan UKGS belum optimal. Penelitian ini bertujuan untuk mengetahui faktor-faktor yang mempengaruhi kinerja perawat gigi dalam pelaksanaan UKGS di Puskesmas wilayah dinas kesehatan Kabupaten Bandung.

Jenis peneltian adalah metode eksplanatori dengan pendekatan cross sectional. Pengambilan data dilakukan dengan wawancara dan observasi. Jumlah sampel 50 perawat gigi. Analisa data secara univariat, bivariat dengan uji chi square dan multivariat dengan regresi logistik.

Hasil penelitian menunjukkan bahwa kinerja Perawat gigi dalam pelaksanaan UKGS di Dinas Kesehatan Kabupaten Bandung termasuk dalam kategori kurang sebesar 58,0\% dan kinerja baik sebesar 42.0\%. Variabel yang berhubungan langsung dengan kinerja perawat gigi adalah pelatihan, pengetahuan dan motivasi. Variabel paling berpengaruh terhadap kinerja perawat Gigi yaitu pelatihan (OR.20.931). Kesimpulan perawat gigi yang sering mengikuti pelatihan akan mempunyai kinerja 21 kali lebih baik dibanding dengan perawat gigi dengan pelatihan kurang dalam pelaksanaan kegiatan UKGS.
\end{abstract}

Kata kunci : Kinerja, perawat gigi, kegiatan, UKGS

\begin{abstract}
In Bandung District data showed that many students suffer from bleeding gums, dental caries in students tend to rise nearly $90 \%$ in elementary school students, the average incidence of dental caries occur in the age group 6-12 years with DMF-T = 2,7. Where as the target of Healthy Indonesia 2010 on caries incidence is not more than two. Not optimal oral health care in children aged 6-12 years (primary school age), showed that the performance of dental nurses in UKGS care services was not optimal.

This study was an explanatory research with cross sectional approach. Data were collected by interview and observation. The number of samples is 50 dental nurses.

The results showed that the performance of dental nurses in the implementation of the District Health Office UKGS in Bandung is only about $58.0 \%$ and that have a good performance is only $42.0 \%$. Variables that are directly related to the performance of dental nurses in the implementation of UKGS are training, knowledge and motivation The variables most affect the dental nurse performance of the implementation UKGS was training (RP 20.931) means that dental nurse with a good level of 21 times likely to have a better performance compared to the dental nurse with less knowledge, and the most influential factor was training. Means that dental nurses who have high training will have 21 times better performance compared with dental nurses with low training in the implementation of UKGS.
\end{abstract}

Key words : Performance, dental nurse at implementation, UKGS

${ }^{1)}$ Dosen Jurusan Keperawatan Gigi Poltekkes Kemenkes Bandung

${ }^{2,3)}$ Dosen Promosi Kesehatan Universitas Diponegoro

${ }^{凶 1}$ : Widaningrumn@gmail.com 


\section{PENDAHULUAN}

Pembangunan kesehatan saat ini diarahkan pada peningkatan kualitas sumber manusia serta kualitas kehidupan dan harapan hidup manusia. Untuk membuat sistem pengelolaan pelayanan kesehatan yang baik memerlukan perhatian terhadap sumber daya manusia yang tersedia. Tenaga kesehatan merupakan salah satu unsur penting dalam pelaksanaan upaya kesehatan untuk dapat menyelenggarakan pelayanan profesional (DinKes Kab.Bandung, 2008)

Menurut UU No.29 Tahun 2004 Tentang Praktik Kedokteran dan Permenkes No. 1419 Tahun 2005 tentang tugas pokok dan fungsi dari tenaga medis dokter gigi dan tatacara praktek kedokteran gigi, akan berpengaruh kepada pelayanan kesehatan gigi di lapangan seperti Puskesmas (DinKes Kab.Bandung, 2008)

Pelayanan kesehatan gigi di Puskesmas, selain dokter gigi adapula tenaga kesehatan lain dibidang kesehatan gigi yaitu perawat gigi. Sesuai Keputusan Menteri Kesehatan No. 1035/MENKES/SK/IX/1998, yang dimaksud dengan Perawat gigi adalah seseorang yang telah selesai mengikuti pendidikan perawat gigi yang telah diakui pemerintah dan lulus ujian sesuai dengan persyaratan yang berlaku.

Menurut SKRT 2000 prevalensi karies di Pulau Jawa sebesar 56,8\% ,dan sebanyak 56,8\% penduduk umur 10 tahun keatas menderita kerusakan gigi permanen yang belum ditangani. Pada umur 10-12 tahun dan umur 15-25 tahun lebih banyak menderita karies aktif. Di Jawa Barat prevalensi karies anak adalah $90 \%$ dan ratarata DMF-T =4,6. Magdarini dkk (2005) mengemukakan adanya peningkatan insiden karies gigi 0,5 gigi / anak dalam setiap satu tahun di 3 tempat yang ada di Jawa barat kemudian kebutuhan akan tumpatan sangat tinggi $98 \%$ untuk anak SD membutuhkan perawatan.

Kegiatan pelayanan asuhan belum optimal, hal ini dapat dilihat dari masih tingginya kerusakan gigi dapat dilihat dengan indeks DMF-T (Decay Meesing Feeling-Tooth) untuk kelompok 15 tahun 1,1; kelompok 18 tahun 1,4; 34 - 44 tahun 4,5; dan > 65 tahun 18,3 (DinKes Kab. Bandung, 2009).

Pencapaian target program usaha kesehatan gigi dan mulut di Dinas Kesehatan Kabupaten Bandung belum maksimal. Kejadian kerusakan gigi berlubang atau karies gigi yang tinggi juga ditemukan di Kabupaten Bandung. Data selama 4 tahun terakhir menunjukkan bahwa karies gigi cenderung meningkat, rata-rata kejadian karies gigi tetap keseluruhan golongan umur dengan indikator DMF-T pada tahun 2008 memperlihatkan bahwa DMF-T $=2,9$, tahun 2009 DMF-T =3,0, tahun 2010 DMF-T = 3,1 tahun 2011 DMF-T $=3,2$. Sedangkan target Indonesia sehat diharapkan kejadian karies adalah tidak boleh lebih dari 2 dan menurut WHO adalah tidak boleh lebih dari 1. Karies di Kabupaten Bandung pada anak balita prevalensi karies adalah $87 \%$ dengan def (decay ektraksi filling) $=5,7$. Lebih memprihatinkan lagi karies banyak terjadi pada kelompok umur 6-12 tahun yaitu DMFT rata-rata $=1,6$, padahal kelompok umur ini gigi permanennya baru saja mengalami pergantian dari gigi susu (Depkes RI, 2007). Berdasarkan laporan Profil Kesehatan Gigi menunjukkan bahwa $62,4 \%$ penduduk merasa terganggu pekerjaannya atau murid sekolah tidak masuk sekolah dengan alasan karena sakit gigi, dengan nilai rata-rata tidak masuk sekolah karena sakit gigi adalah 3,86 hari. Kondisi ini menunjukkan bahwa penyakit gigi walaupun tidak menimbulkan kematian, tetapi dapat menurunkan produktivitas kerja dan karena Standar Pelayanan Maksimal (SPM) yang ditargetkan oleh Dinas Kesehatan Kabupaten belum terpenuhi. Pelayanan kesehatan gigi dan mulut pada anak usia 6 - 12 tahun (usia sekolah) belum optimal, menunjukkan bahwa kinerja perawat gigi pada pelayanan UKGS belum optimal. Target pencapaian cakupan yang diharapkan adalah 100\% SD melaksanakan pendidikan / penyuluhan kesehatan gigi dan mulut, $80 \%$ minimal 
jumlah SD yang ada melaksanakan sikat gigi massal dan 50\% minimal murid selesai perawatan dari jumlah murid yang memerlukan perawatan, $30 \%$ minimal murid yang menderita karies dari seluruh murid yang ada, Jumlah frekuensi pembinaan yang diharapkan adalah minimal 2 kali tiap tahun (Depkes RI, 2002).

Sekolah Dasar UKGS yang berada di wilayah kabupaten Bandung 80\% sudah malaksanakan UKGS tahap II/paket standar UKS. Pelayanan kesehatan gigi dan mulut untuk murid SD dan MI sudah terjangkau oleh tenaga kesehatan namun fasilitas kesehatan yang terbatas. Salah satu keberhasilan kegiatan UKGS tergantung dari kinerja perawat gigi dalam melaksanakan peran dan fungsinya secara profesional. Selama ini sebagian besar perawat gigi hanya melaksanakan penyuluhan, sikat gigi massal dan merujuk. Padahal seorang perawat gigi bukan hanya memberikan informasi, sikat gigi massal, dan merujuk tetapi harus melaksanakan pelayanan yang lain yaitu harus melatih kader kesehatan untuk guruguru penjakes, melaksanakan pencabutan gigi sulung yang sudah waktunya tanggal, melakukan perawatan gigi berlubang terutama untuk gigi tetap dan memberikan pengobatan yang sakit dan melakukan rujukan untuk kasus yang tidak bisa ditangani oleh perawat gigi di UKGS.

Berdasarkan uraian diatas penulis ingin mengetahui pengaruh kinerja Perawat Gigi dalam pelaksanaan kegiatan UKGS.

Tujuan penelitian untuk mengetahui faktor-faktor yang paling berpengaruh terhadap kinerja perawat gigi dalam pelaksanaan UKGS di Kabupaten Bandung.

\section{METODE PENELITIAN}

Metode penelitian yang digunakan penelitian kuantitatif dengan explanatory riset. Subyek penelitian adalah seluruh perawat gigi 50 orang yang berstatus PNS dan masa kerja lebih dari satu tahun di puskesmas wilayah Kabupaten Bandung.
Instrumen yang digunakan adalah kuesioner dan ceklis observasi kinerja perawat gigi dalam pelaksanaan UKGS. Analisa data yang digunakan adalah univariat, bivariat dengan uji chi square dan multivariat dengan regresi logistik.

\section{HASIL DAN PEMBAHASAN}

\section{Hasil Pengolahan Data Secara Deskriptif (Analisis Univariat)}

Analisa univariat dilakukan dengan mendiskripsikan setiap variabel, baik variabel independen maupun variabel dependen sebagai berikut :

\section{A. Karakteristik Responden}

Tabel 1. Distribusi Karakteristik Responden Berdasarkan Umur

\begin{tabular}{lcc}
\hline \multicolumn{1}{c}{ Umur Responden } & Jumlah & $\%$ \\
\hline$<30$ tahun & 28 & 56,0 \\
$>30-40$ & 22 & 44,0 \\
\hline Total & 50 & 100,0 \\
\hline
\end{tabular}

Berdasarkan Tabel 1 dijelaskan bahwa latar belakang umur terbanyak perawat gigi adalah dibawah umur 30 (56\%).

Tabel 2. Distribusi Karakteristik Responden Berdasarkan Tingkat Pendidikan

\begin{tabular}{lcc}
\hline Pendidikan & Jumlah & $\%$ \\
\hline Diploma & 33 & 66,0 \\
Non diploma & 17 & 34,0 \\
\hline Total & 50 & 100,0 \\
\hline
\end{tabular}

Berdasarkan Tabel 2 bahwa Pendidikan perawat gigi di Kabupaten Bandung sebagian besar adalah Diploma $(66,0 \%)$.

Tabel 3. Distribusi Karakteristik Responden Berdasarkan Masa Kerja

\begin{tabular}{lcc}
\hline \multicolumn{1}{c}{ Masa kerja } & Jumlah & $\%$ \\
\hline $5-10$ tahun ( baru ) & 7 & 14,0 \\
$>10$ tahun (lama ) & 43 & 86,0 \\
\hline Total & 50 & 100,0 \\
\hline
\end{tabular}

Berdasarkan Tabel 3 bahwa masa kerja perawat gigi di Kabupaten Bandung 
mempunyai masa kerja lebih dari 10 tahun yaitu sebanyak $86,0 \%$.

Tabel 4. Distribusi Karakteristik Responden Berdasarkan Pelatihan

\begin{tabular}{lcc}
\hline Variabel & Jumlah & $\%$ \\
\hline Kurang & 37 & 74,0 \\
Banyak & 13 & 26,0 \\
\hline Total & 50 & 100.0 \\
\hline
\end{tabular}

Berdasarkan Tabel 4 bahwa Perawat gigi yang belum pernah mendapat pelatihan tentang UKGS sebanyak 74,0\%.

\section{B. Kemampuan (pengetahuan dan Keterampilan) Perawat Gigi dalam pelaksanaan kegiatan UKGS}

Tabel 5. Distribusi Kemampuan Responden berdasarkan Pengetahuan

\begin{tabular}{llcc}
\hline Variabel & Pengetahuan & Jumlah & $\%$ \\
\hline Kurang & $:($ Skor $\leq 70 \%)$ & 24 & 48,0 \\
Baik & $:($ Skor $>70 \%)$ & 26 & 52.0 \\
\hline Total & & 50 & 100,0 \\
\hline
\end{tabular}

Berdasarkan Tabel 5 bahwa dari 50 orang perawat gigi, sebanyak $52,0 \%$ perawat gigi memiliki pengetahuan baik.

Tabel 6. Distribusi Kemampuan Responden Berdasarkan keterampilan

\begin{tabular}{lcc}
\hline \multicolumn{1}{c}{ Variabel Keterampilan } & Jumlah & $\%$ \\
\hline Kurang : (skor $<70.00)$ & 24 & 48.0 \\
Baik $\quad$ : $($ skor $\geq 70.00)$ & 26 & 52.0 \\
\hline Total & 50 & 100.0 \\
\hline
\end{tabular}

Berdasarkan Tabel 6 bahwa sebanyak $52 \%$ perawat gigi memiliki ketrampilan yang baik.

\section{Motivasi perawat Gigi dalam kegiatan pelaksanaan UKGS}

Tabel 7. Deskripsi Kemampuan Responden Berdasarkan Motivasi

\begin{tabular}{lcc}
\hline Variabel Motivasi & Jumlah & $\%$ \\
\hline Motivasi Kurang & 27 & 54.0 \\
Motivasi Baik & 23 & 46,0 \\
\hline Total & 50 & 100.0 \\
\hline
\end{tabular}

Berdasarkan Tabel 7 sebanyak 54\% perawat gigi mempunyai motivasi yang kurang tentang pelaksanaan UKGS.

\section{Sikap perawat Gigi dalam kegiatan pelaksanaan UKGS}

Tabel 8. Distribusi Kemampuan Responden Berdasarkan Sikap

\begin{tabular}{llcc}
\hline Sikap & & Jumlah & $\%$ \\
\hline Kurang & $:($ Skor $<60)$ & 19 & 38,0 \\
Baik & $:($ Skor $\geq 60)$ & 31 & 62,0 \\
\hline Total & & 50 & 100.0 \\
\hline
\end{tabular}

Berdasarkan Tabel 8 bahwa sebanyak $62,0 \%$ perawat gigi mempunyai sikap yang baik dalam pelaksanaan kegiatan UKGS.

\section{E. Supervisi Atasan perawat gigi dalam kegiatan pelaksanaan UKGS}

Tabel 9. Deskripsi Kemampuan Responden Berdasarkan Supervisi

\begin{tabular}{llcc}
\hline Supervisi & & Jumlah & $\%$ \\
\hline Kurang & $:(\leq$ median 16) & 29 & 58,0 \\
Baik & $:(>$ median 16) & 21 & 42,0 \\
\hline Total & & 50 & 100,0 \\
\hline
\end{tabular}

Berdasarkan Tabel 9 menunjukkan sebagian besar responden menyatakan bahwa supervisi pimpinan tentang pelaksanaan UKGS kurang baik yaitu 58,0\%.

Untuk mengetahui hubungan antara variabel independen dan dependen digunakan uji Chi Square.

Tabel 10. Hasil analisis bivariat antara variabel independen dan variabel dependen

\begin{tabular}{lcc}
\hline \multirow{2}{*}{ Variabel } & \multicolumn{2}{c}{ Kinerja perawat Gigi } \\
\cline { 2 - 3 } & Nilai $\mathrm{P}$ & Keterangan \\
\hline Jenis kelamin & 0,368 & Tidak signi fikan \\
\hline Pendidikan & 0,153 & Tidak signifikan \\
\hline Umur & 1,000 & Tidak signifikan \\
\hline Masa Kerja & 1,000 & Tidak signifikan \\
\hline Pelatihan & $\mathbf{0 , 0 0 1}$ & Signifikan \\
\hline Pengetahuan & $\mathbf{0 , 0 0 1}$ & Signifikan \\
\hline Keterampilan & 0,810 & Tidak signifikan \\
\hline Motivasi & $\mathbf{0 , 0 0 5}$ & Signifikan \\
\hline Sikap & 0,382 & Tidak signifikan \\
\hline Supervisi & 1,000 & Tidak signifikan \\
\hline
\end{tabular}


Berdasar Tabel 10 menunjukkan terdapat 3 variabel dari 9 variabel independen yang menunjukkan adanya hubungan dengan Kinerja Perawat Gigi dalam pelaksanaan kegiatan paket standar UKGS di Dinas Kesehatan Kabupaten Bandung yaitu pelatihan, pengetahuan dan motivasi. Variabel independen yang mempunyai hubungan dengan variabel dependen dapat dianalisis ke multivariat dengan analisis regresi logistik untuk mengetahui pengaruhnya secara bersamasama. Hasil uji regresi logistik sebagai berikut :

Tabel 11. Hasil analisis regresi logistic kinerja perawat gigi dalam pelaksanaan kegiatan program UKGS di Kabupaten Bandung

\begin{tabular}{|c|l|r|r|r|r|r|r|r|r|}
\hline \multirow{2}{*}{ No } & Variabel & B & S.E. & Wald & df & Sig. & Exp(B) & $\begin{array}{c}95,0 \% \\
\text { EXP }\end{array}$ & $\begin{array}{c}\text { C.I.for } \\
\text { (B) }\end{array}$ \\
\hline 1 & & & & & & & & Lower & \multicolumn{1}{c|}{ Upper } \\
\hline 2 & Pengetahuan & 1.724 & .833 & 4.289 & 1 & .038 & 5.609 & 1.097 & 28.686 \\
\hline 3 & Motativan & 3.041 & 1.090 & 7.787 & 1 & $\mathbf{. 0 0 5}$ & $\mathbf{2 0 . 9 3 1}$ & $\mathbf{2 . 4 7 2}$ & 177.201 \\
\hline
\end{tabular}

Berdasarkan Tabel 11 menunjukkan hasil uji statistik regresi logistic variable yang paling berpengaruh adalah variabel pengetahuan dengan nilai signifikansi 0,005 dan odds ratio (OR) adalah 20.931 artinya bahwa perawat gigi yang pelatihannya baik kemungkinan 21 kali lebih baik melaksanakan kegiatan UKGS dibandingkan dengan perawat gigi yang pelatihannya kurang dalam melaksanaan kegiatan program UKGS.

Hasil penelitian menunjukkan bahwa kinerja Perawat gigi dalam pelaksanaan kegiatan UKGS di Kabupaten Bandung adalah kurang yaitu sebesar 58,0\% dan yang mempunyai kinerja baik hanya $42,0 \%$. Kurangnya kinerja perawat gigi berkaitan dengan beberapa target yang dicapai tidak sesuai yang ditetapkan oleh dinas Kesehatan Kabupaten Bandung. Perawat gigi kurang mengikuti pelatihan di Dinas Kesehatan Kabupaten Bandung yaitu sebanyak $74 \%$ belum pernah mengikuti pelatihan tentang pelayanan asuhan. Hal ini karena keterbatasan jumlah perawat gigi yang ada di Puskesmas sebagain besar hanya terdapat satu perawat gigi sehingga kesempatan untuk mengikuti pelatihan masih kurang. Sejalan dengan pendapat Harianja (2002), pelatihan merupakan upaya untuk mengembangkan sumber daya manusia, terutama untuk mengembangkan kemampuan intelektual dan kepribadian. Pelatihan juga merupakan bagian dari suatu proses pendidikan yang bertujuan untuk meningkatkan pengetahuan, keterampilan dan kemampuan pegawai.

Kurangnya kinerja perawat gigi disebabkan oleh motivasi perawat gigi yang kurang yaitu sebanyak $54 \%$ perawat gigi di kabupaten Bandung mempunyai motivasi kurang untuk melaksanakan kegiatan UKGS ini mungkin disebabkan oleh tidak adanya imbalan yaitu berupa reward ataupun punishment dari atasan perawat gigi. Motivasi adalah kondisi yang menggerakkan pegawai agar mampu mencapai tujuan dari motifnya. Sedangkan motivasi dikatakan sebagai energi untuk membangkitkan dorongan dalam diri. Kuesmono (2005) mengatakan motivasi seseorang bekerja tergantung pada reward yang diterimanya dan punishment yang akan dialaminya nanti. Pendidikan perawat gigi meliputi 32\% lulusan sekolah pengatur rawat gigi (SPRG) dan lulusan Diploma III perawat gigi sebesar 66\%. Menurut Green (2000) bahwa tingkat pendidikan seseorang merupakan faktor pemudah untuk terjadinya perubahan perilaku. Jenjang atau tingkat pendidikan formal yang diikuti petugas ini dapat mempengaruhi kualitas pekerjaan, semakin tinggi jenjang pendidikan petugas semakin tinggi dan semakin terampil pula kemampuan dalam menyelesaikan tugas pekerjaan yang di beban. Menurut teori L Gibson (1986) bahwa skill atau ketrampilan adalah kompetensi yang berhubungan dengan tugas, seperti membimbing sikat massal dan memberikan penyuluhan kesehatan gigi dan ketrampilan membuat perencanaan (POA) untuk UKGS dengan jelas untuk tujuan dan misi. Perawat gigi dikatakan mampu bekerja apabila petugas itu disamping berpengetahuan luas, petugas itu juga terampil dalam melaksanakan kegiatan promotif, preventif dan kuratif sederhana di 
UKGS. Dilihat dari sisi pencapaian target dinas kesehatan, ternyata target yang tidak tercapai paling banyak adalah kegiatan sikat gigi massal. Sikat gigi masal seharusnya 8 kali sekali dalam setahun tetapi kenyataan hanya dilakukan 1-2 kali dalam satu tahun. Berdasarkan penelitian DepKes menunjukkan menyikat gigi mempunyai pengaruh bermakna terhadap keluhan sakit gigi yang berarti seorang yang tidak menyikat gigi mempunyai resiko 14,5 kali sakit gigi dibanding seorang yang menyikat gigi dengan baik. Adapun variabel independent yang menjadi penyebab kurangnya kinerja Perawat gigi dalam pelaksanaan kegiatan UKGS di Dinas Kesehatan Kabupaten Bandung adalah tingkat pelatihan, pengetahuan dan motivasi artinya bahwa Perawat gigi dengan pelatihan baik kemungkinan 21 kali mempunyai kinerja lebih baik dibandingkan dengan perawat gigi pelatihannya kurang dalam pelaksanaan kegiatan UKGS, perawat gigi yang mempunyai motivasi baik kemungkinan 8.5 kali mempunyai kinerja yang lebih baik dibandingkan dengan perawat gigi yang mempunyai motivasi kurang dalam pelaksanaan kegiatan UKGS dan pengetahuan baik perawat gigi kemungkinan 5.6 kali mempunyai kinerja lebih baik dibandingkan perawat gigi dengan pengetahuan kurang. Menurut Bungaria (2004) bahwa ada hubungan signifikan positif antara variabel pengetahuan dengan variabel kinerja perawat gigi, yakni semakin tinggi tingkat pengetahuan akan semakin tinggi kinerja perawat gigi berdasarkan tugas pokok dan fungsinya.

\section{KESIMPULAN}

1. Pelatihan tentang pelaksanaan kegiatan UKGS tidak pernah diikuti Perawat Gigi sebanyak 74,0\% sedangkan Perawat Gigi yang pernah mengikuti pelatihan sebesar $36 \%$. Perawat gigi yang sering mengikuti pelatihan kemungkinan 21 kali mempunyai kinerja yang lebih baik dibandingkan dengan Perawat gigi yang kurang mengikuti pelatihan.

2. Pengetahuan perawat gigi tentang pelaksanaan kegiatan UKGS baik sebesar $52,0 \%$, sedangkan responden yang mempunyai pengetahuan kurang sebesar $48,0 \%$. Pengetahuan baik perawat gigi kemungkinan 5.6 kali mempunyai kinerja lebih baik dibandingkan perawat gigi dengan pengetahuan kurang.

3. Motivasi perawat gigi dalam melaksanakan kegiatan pogram UKGS sebagian besar mempunyai motivasi yang kurang yaitu 54,0\%. Sedangkan responden yang pempunyai motivasi baik sebesar $46 \%$. Perawat gigi yang mempunyai motivasi baik kemungkinan 8.5 kali mempunyai kinerja yang lebih baik dibandingkan dengan perawat gigi yang mempunyai motivasi kurang.

\section{DAFTAR PUSTAKA}

Asnita Bungaria. 2004. Analisis kinerja perawat gigi berdasarkan tugas pokok dan fungsinya dibalai pengobatan gigi Puskesmas Kota Medan.

Bandung, Profil Dinas Kesehatan Kabupaten. 2009. Dinas Kesehatan Kabupaten Bandung. Bandung

Depkes RI. 2007. Survey kesehatan Rumah Tangga. Jakarta : Depkes RI.

Dinas Kesehatan Kabupaten Bandung. 2008. Profil Kesehatan Kabupaten Bandung Tahun 2008. Bandung.

DepKes RI. 2000. Pedoman Upaya Pelayanan kesehatan Gigi dan Mulut di Puskesmas. Jakarta: Direktorat Jendral Pelayanan Medik.

DepKes RI,2002, Standar pelayanan Asuhan Kesehatan Gigi dan Mulut Puskesmas Perkotaan. Jakarta Direktorat Jendral Pelayanan Medik. 
Eriyati. Faktor-faktor yang Mempengaruhi Kinerja Perawat Gigi Lulusan Jurusan Gigi Poltekkes Kemenkes Padang berdasarkan Kompetensi pada Puskesmas di Sumatera Barat Tahun 2011 (Tesis) Universitas Gadjahmada. http://etd.ugm.ac.id. Diakses tanggal 20 Oktober 2011

Firman, Heri. Standar Kinerja karyawan. s.1.: Available from : URL : http//www.ede.gov/nsidod/Eid /eid. htm, ( serial on line ) 2009 Februari Maret (edisi April 3).

Gibson, J.L, Ivancevich, J.M. Donnely, J.H. 1986. Organisasi Perilaku, Struktur, Proses. Jakarta : Binarupa Aksara.

Handoko, Hani T. 2002. Management Personalia dan sumber Daya Manusia. Yogjakarta : Penerbit UII Press.

Husaini., Usman. 2008. Management Teori \& Praktek Pendidikan. Jakarta : Bumi Aksara

Keputusan Menteri Kesehatan RI. No.1035/MENKES/SK/IX/1998 tentang Perawat Gigi.

Keputusan menteri Kesehatan RI. 2006. No.284/MENKES/SK/IV/2006 tentang Standar Pelayanan Asuhan Kesehatan Gigi dan Mulut.

Kuesmono, Teman. 2005. Pengaruh Budaya Organisasi terhadap Motivasi, dan Kepuasan Kerja Serta Kinerja karyawan pada Sub Sektor Pengolahan Kayu Skala Menengah di Jawa Timur, Jurnal Manajemen dan Kewirausahaan ISSN 1411 - 1438 Vol 7, No 2

2009. Pengembangan Sumber Daya Manusia . Jakarta Rineka.
Kementerian Kesehatan RI. 2009. Kebijakan Pelayanan Kedokteran Gigi Keluarga. Jakarta : Nomor1415/Menkes/SK/X/ 2005.

Menteri Negara Pendayagunaan Aparatur Negara R.I. 2001. Jabatan Fungsional perawat gigi dan angkat kreditnya. Jakarta : Aparatur Negara nomor 22/Kep/M.PAN/ 4/2001.

Mangkunegara Prabu, A.2005. Perilaku dan Budaya Organisasi. Bandung : Adithama.

Magdarini D., Agus Sintawati dan Tony Murwanto. Status kesehatan Gigi, performent Index anak sekolah dasar di Kabupaten Cianjur, Karawang dan Serang, Media Litbang Kesehatan, Volume XV nomor 4. 2005

Rahmawati, Kusdiyah. I, 2008 Managemen Sumber Daya Manusia. Yogyakarta

Robins, Stephen, P. 2007. Management. Jakarta : PT. Macana Jaya Cemerlang.

Siagian, Sondang P. 2007. Teori Pengembangan Organisasi. Jakarta : Bumi Aksara

Syafri, Prawira. 2008. Pendekatan Sistem dalam Analisa Kinerja. Jakarta : Pernerbit. MSDM.

Sofyandi, H. 2007. Prilaku Organisasi. Yogjakarta : Graha Ilmu.

Sopiah, 2008. Prilaku Organisasi. Yogjakarta : Andi Yogjakarta

Saleh, Muhammad. 2010. Pengaruh Kinerja Perawat Gigi terhadap Tingkat Kepuasan Pasien di Puskesmas Pattalassang Kecamatan Pattalassang Kabupaten Takalar. Jurnal Media Kesehatan Gigi. ISSN 
2087 - 0051. Edisi 1, Mei 2010.

http://isjd.pdii.lipi.go.id. Diakses tanggal 20 Oktober 2012.

Usman, H.2009. Management (teori,praktik, dan riset Pendidikan). Jakarta : P.T Bumi Aksara.

Wirawan, W. 2009. Evaluasi kinerja Sumber Daya Manusia. Jakarta: Salemba Empat.

Widiyastuti Tri dan Neneng Nurjanah, 2003. Persepsi dokter gigi di wilayah kabupaten Bandung terhadap kompetensi tenaga perawat gigi. Risbinakes Poltekes Depkes. 